\title{
Workshop attendance as a mode of learning:
}

Citation for published version (APA):

de Grip, A., \& Pleijers, A. (2019). Workshop attendance as a mode of learning: Evidence from the Netherlands. Maastricht University, Graduate School of Business and Economics. GSBE Research Memoranda No. 024 https://doi.org/10.26481/umagsb.2019024

Document status and date:

Published: 02/09/2019

DOI:

10.26481/umagsb.2019024

Document Version:

Publisher's PDF, also known as Version of record

\section{Please check the document version of this publication:}

- A submitted manuscript is the version of the article upon submission and before peer-review. There can be important differences between the submitted version and the official published version of record.

People interested in the research are advised to contact the author for the final version of the publication, or visit the DOI to the publisher's website.

- The final author version and the galley proof are versions of the publication after peer review.

- The final published version features the final layout of the paper including the volume, issue and page numbers.

Link to publication

\footnotetext{
General rights rights.

- You may freely distribute the URL identifying the publication in the public portal. please follow below link for the End User Agreement:

www.umlib.nl/taverne-license

Take down policy

If you believe that this document breaches copyright please contact us at:

repository@maastrichtuniversity.nl

providing details and we will investigate your claim.
}

Copyright and moral rights for the publications made accessible in the public portal are retained by the authors and/or other copyright owners and it is a condition of accessing publications that users recognise and abide by the legal requirements associated with these

- Users may download and print one copy of any publication from the public portal for the purpose of private study or research.

- You may not further distribute the material or use it for any profit-making activity or commercial gain

If the publication is distributed under the terms of Article $25 \mathrm{fa}$ of the Dutch Copyright Act, indicated by the "Taverne" license above, 


\section{Maastricht University}

Andries de Grip, Astrid Pleijers

Workshop attendance as a mode of learning: Evidence from the Netherlands

RM/19/024

\section{GSBE}

Maastricht University School of Business and Economics

Graduate School of Business and Economics

P.O Box 616

NL-6200 MD Maastricht

The Netherlands 


\title{
Workshop attendance as a mode of learning: evidence from the Netherlands
}

\author{
Andries de Grip and Astrid Pleijers
}

Andries de Grip*

ROA, Maastricht University

P.O. Box 616

6200 MD Maastricht

The Netherlands

Tel.: (+31)433883647

a.degrip@maastrichtuniversity.nl

* corresponding author
Astrid Pleijers

Statistics Netherlands (CBS)

P.O. Box 4481

$6401 \mathrm{CZ}$ Heerlen

The Netherlands

Tel.: (+31)455716143

a.pleijers@cbs.nl

Keywords: workshops, training, informal learning, work-related learning, human resource development, absorptive capacity, human capital theory.

Acknowledgements: We thank Maria Ferreira, Annemarie Künn-Nelen, Mien Segers, Wendy Smits for their valuable comments on earlier drafts of the paper. 


\begin{abstract}
Although workshop attendance appears to be as high as participation in training, this paper is the first study in the educational science, human resource management and labour economics literature that explores the drivers of workshop attendance among the working population. In our analysis of the Dutch Adult Education Survey, we find that workshop attendance is highest among managers and professionals, in contrast to their participation in training. These results confirm our expectation that workshop attendance is important in acquiring state-of-the art knowledge on external developments as a dominant source of competitive advantage for the organization. Furthermore, workshop attendance is positively related to individuals' level of education. Particularly in workers' mid-career years, attending workshops appears to be an important mode of learning: Workshop attendance is peaking at the age of 47 . Moreover, we find that workshop attendance is complementary to training participation instead of a substitute. Our results show that there are interesting differences between the drivers of workshop attendance and those of participation in training and informal learning.
\end{abstract}

\title{
Introduction
}

Many studies in the fields of educational science, human resource management (HRM) and labour economics analyse the extent to which participation in formal training courses is related to personal, job, or organisation characteristics (for an overview of these studies, see, e.g. Kyndt \& Baert, 2013; Bassanini et al., 2007). More recently, an interest has emerged in other modes of learning, such as informal learning in the workplace, by either learning by doing or learning from peers (e.g. Kyndt \& Baert 2013; Noe et al. 2013; Froehlich et al. 2014; De Grip et al. 2016).

However, learning from others is not necessarily restricted to those employed on the same team or in the same organisation. Darr et al. (1995) show that there are also considerable transfers of knowledge across organisations. Building on early literature on social networks (Tushman 1977), they emphasize that regular communication and personal acquaintances are potential mechanisms for the transfer of knowledge between workers who are employed in different organisations. From this perspective, attending a workshop can be an interesting mode of learning from other professionals in the same professional field or industry sector, either by listening to the lectures of experts or by extensive networking with peers participating in the 
same workshop. This holds all the more because many organisations are aware of the dynamic external environment in which they operate and the importance of state-of-the art information on market developments, research and development (R\&D), best practices in workplace innovation, changes in legislation, and so forth. This turbulence in the business environment makes state-of-the-art knowledge in these fields a dominant source of competitive advantage, since it contributes to the organisation's 'absorptive capacity' (e.g. Jansen et al., 2005). However, as the speed of these developments in most professions is extremely high, this knowledge cannot be acquired by participating in a training course (Burke and Hutchins, 2007) but requires constant learning, which makes that professional organisations define relevant professional learning activities very broadly, including workshop and conference participation (Fenwick, 2012).

Due to the combination of lectures of experts with extensive networking with peers attending the same workshop, workshop participation is at the edge of formal and informal learning. As workshops and conferences occur within a context that is specifically designed for learning, Kyndt and Baert (2013) qualify it as a mode of formal learning, whereas Rüber and Bol (2017) place it as a mode of informal learning taking into account the entire social context of participating in a conference. However, we agree with Kyndt and Baert (2013) that formal and informal learning should not be dichotomized.

The importance of workshop attendance in many professional fields raises the question on the determinants of workshop attendance. Which kind of workers participate most often in a workshop and to what extent is this related to their profession or the sector in which they are employed? In this paper, we analyse the drivers of workshop attendance of the Dutch working population between the ages of 25 and 65. Moreover, we compare our findings on the determinants of workshop attendance with the drivers of other modes of learning, namely, short courses, long courses, and informal learning.

In exploring the drivers of workshop participation we build on Human capital theory that explains the decision on training participation by a cost-benefit analysis, i.e., workers and their employers only participate in workshop participation if future benefits exceed the costs ${ }^{1}$. As

\footnotetext{
${ }^{1}$ Human capital was launched in the 1960s, in a special issue if the Journal of Political Economy that included the seminal paper of Gary Becker (1962) which was the basis of his work for which he received the Nobel Prize in economics in 1992.
} 
mentioned above, the absorptive capacity literature (e.g. Jansen et al., 2005) more specifically explains the benefits of workshop participation in terms of gathering the state-of-the art knowledge that is highly relevant for the competitive position of the organization.

Although workshops and seminars are sometimes part of an indicator including all modes of training (e.g. Froehlich et al., 2014), as far as we know, this is the first study that explicitly explores the drivers of workshop attendance. We define workshop attendance as a special type of non-formal learning that is not recognized by the relevant national (or equivalent) authorities, as is done in Eurostat's Classification of Learning Activities (Eurostat, 2015). Eurostat (2015, p. 21) defines workshops broadly, including (work related) conference and seminar participation: "Sessions combining theoretical instruction with "hands-on" training provided during a seminar or conference." In such sessions, participants contribute actively and exchange their ideas. Their duration varies form a few hours to several days. A conference is a more largescale meeting on a specific theme for which business people or scientists participate. During a conference, thoughts about a certain theme are formed and the exchange of ideas is central. Often there are a chairperson, several speakers and discussion leaders. However, we separate workshops from short or long training courses. A workshop or conference differs from a course in the sense that a course is broader, deeper and more intensive than a workshop or conference. Workshops and conferences therefore generally have a limited duration. Many workshops and conferences take place in an inter-organisational context, although attending a workshop in an intra-organisational setting is also possible. As Darr et al., (1995) illustrate, conferences are ideally suited to network with people from the same field or branch outside the organisation.

In addition to workshops, we distinguish courses (short and long) and informal learning. Courses are typically subject-oriented. These are taught by one or more persons specialised in the field(s). The predominant way of teaching in a course is transmission of knowledge, as opposed to learning by active participation in a workshop. A course may or may not include discussion on a given subject, such as job-related courses (Eurostat, 2015). Short courses are also non-formal and have a defined duration of one day to six months. Long courses are defined as institutionalized learning activities with a duration of at least six months that lead to a learning achievement that can be positioned in the National Framework of Qualifications, socalled formal education. The National Framework of Qualifications recognizes learning activities constituted of structured hierarchical programmes with a chronological succession of levels and grades, admission requirements, and formal registration. Informal learning is defined 
as deliberate, non-institutionalised learning, as opposed to random learning. It can take place almost anywhere: at work, within the family, or with friends (Eurostat, 2015).

The Dutch Adult Education Survey (AES) data we use show that workshop attendance is a non-negligible mode of learning, since in $201140 \%$ of the Dutch working population attended a workshop, whereas $41 \%$ participated in a short or long training course and $32 \%$ in informal learning.

This article is organised as follows: The following section briefly discusses the scarce literature on workshop attendance. We then describe our data and methodology and discuss the results of our empirical analyses. The last section presents our conclusions and discusses the limitations of our analysis, as well as suggestions for further research.

\section{Prior research and theoretical framework}

Various studies focus on the relevance of learning from peers (e.g. Froehlich et al., 2014; De Grip et al., 2016) as a major complement to participating in training courses. However, these studies focus on learning from teammates or supervisors in the same organisation. In neither the educational science, human resource management (HRM) nor labour economics literature, there are studies on the drivers or impact of workshop attendance. In their study on the acquisition, transfer and depreciation of knowledge in service organisations, Darr et al. (1995) show that the higher transfer of skills within pizza store franchises compared to the transfer of skills between franchises is related to the higher frequency of meetings, personal acquaintances, and phone calls. The authors also illustrate their findings by the anecdotal example of a franchisee who recommended a new method of placing pepperoni on pan pizzas at a quarterly workshop of franchisees. Soon after the meeting, this new method - which resulted in finished pan pizzas with more equally distributed pepperoni - was in use in all pizza stores in the region and, within a year, in almost all stores in the United States. This example shows that meetings with other professionals outside one's own organisation but employed in the same branch or profession could be an important means for the transfer of knowledge and the diffusion of innovations or best practices.

Llewellyn et al. (2006) study the extent to which a workshop on a bio-economic farming systems model affected the perceptions of the participating farmers of the short-term economic value of some weed management practices and their perceptions of practice efficacy. The 
authors found that the workshop changed participants' perceptions of the economic value of these weed management practices, which also led to more growers deciding to adopt those practices. Brockmeyer (1998) finds similar positive changes in the beliefs and instructional practices of science teachers resulting from participation in a summer workshop that promoted extended inquiry-based instruction. These two studies show that workshops could be particularly successful for the diffusion of best practices in a sector.

From a Human capital theory perspective the participation in a workshop can therefore been seen as an investment in gathering information on these best practices. The absorptive capacity theory more specifically explains the benefits of workshop participation. In their seminal paper, Cohen and Levinthal (1990) developed a "new perspective on learning and innovation", in which they introduced a knowledge-based perspective of the firm. As Jansen et al. (2005) argue, the turbulence of the business environment makes state-of-the art knowledge in fields as market developments, research \& development, workplace innovation, and changes in legislation a dominant source of competitive advantage for the organisation. In the literature on the organisation's absorptive capacity, 'exploratory learning' initiates the organisation's learning process (Lichtenthaler, 2009). McGrath (2001, p.118) defines exploratory learning as: "the search for new organizational routines and the discovery of new approaches to technologies, businesses, processes, or products". This need for exploratory learning explains the relevance of workshop attendance for higher-educated employees in charge of making professional or managerial decisions. Attending workshops could be an important means for exploratory learning ${ }^{2}$, since it helps both managers and professional staff to acquire new knowledge and best practices in their field of expertise as well as to extend their external networks in these issues. We are aware of the fact that the nature of the survey data we use does not allow us to test whether specific individual learning processes actually occur. However, following the multidisciplinary literature in this field (e.g. Froehlich et al., 2014; De Grip et al., 2016), we use the expected learning from peers and experts at workshops as a means to derive our hypotheses on workshop attendance. We therefore advance the following two hypotheses:

\section{Hypothesis 1:}

Managers and professionals more often attend workshops than those employed in other occupations do.

\footnotetext{
${ }^{2}$ De Grip and Sauermann (2013) discuss how labour economics and HRM studies can be complementary to the educational science literature in this field.
} 
Hypothesis 2:

Higher educated workers more often attend workshops than those who are lower educated.

\section{Related studies on participation in other learning activities}

Human capital theory also offers the theoretical framework for all control variables in our analyses. From its perspective that both individual workers and their employers only invest in training if future benefits exceed the costs of training, all factors that might affect the costs and/or benefits of workshop attendance are potential confounders of the decision to attend a workshop or not. Harteis et al. (2015) show that for a proper measurement of the drivers of participation in learning activities, it is important to include all relevant confounders in the analysis. In their study on the support employees get for workplace learning, they show that age and gender explain the support employees receive for workplace learning (i.e., firms' investment in workplace learning). However, when they include being employed in better jobs in their analysis, age and gender are no longer significant.

In testing the significance of our hypothesis, we therefore aim to include all relevant confounders. However, since we cannot find any previous studies on the determinants of workshop attendance, we have to build on the empirical Human capital literature on participation in other learning activities such as training and informal learning in order to derive the possibly relevant control variables for our analysis.

Consistent with expectations from Human capital theory, workers who are less able to reap the potential benefits from training, participate less often in training courses, because it is uncertain who will benefit from these investments. This holds particularly for workers with a temporary contract. Booth et al. (2002) and Fouarge et al. (2012) show that those employed in a temporary job and the self-employed participate less often in training than those with permanent contracts. In their study on informal learning, Ferreira et al. (2018) however find that those with a temporary contract more often participate in informal learning.

Human capital theory also explains why Part-time workers less often participate in training. As they work less hours in which they can apply the skills they acquired in a training, the benefits of their training investments will be lower. Kyndt and Baert (2013) find that part-time workers indeed less often participate in learning activities, whereas Greenhalgh and Mavrotas (1996) 
and Nelen and De Grip (2009) show that part-time workers less often participate in training than full-time workers do.

The overview study of Bassanini et al. (2007) shows that training participation among older workers is far lower than among younger age groups. Human-capital theory explains why training participation of older workers is lower. For older workers, training participation is low because organisations and the workers themselves can only benefit from new training investments for a rather short period, since older workers will probably retire in a few years. Fenwick (2012, p. 219) adds an important reason for the low training participation of older professionals: they "resisted being viewed and assessed as 'learners' rather than being respected as knowers who are in control of developing their own knowledge", which brings her to the conclusion that "knowledge dynamics should be foregrounded in discussing professional learning." Ferreira et al. (2018) show that workers' informal learning intensity also decreases with age, whereas Stamov-Roßnagel, (2009) finds that workers older than 50 years particularly have a lower motivation for learning related tasks than younger workers. Finally, Van der Heijden et al. (2009) show that older workers are less involved in networking activities in the workplace. However, as mentioned above, Harteis et al. (2015) find that it is not age as such, which determines their involvement in workplace learning, but being employed in a job in which they get support for learning.

Although Human capital theory is less explicit on its implications on gender differences in the costs and benefits on learning, perceived opportunity costs of the time investment in training might be higher for women, particularly when they have young kids at home. Moreover, gender differences in learning investments might be related to different career ambitions. Grund and Martin (2012) indeed find that, in Germany, female workers participate less often in training. However, Bassanini et al. (2007) show that women participate more often in training than men, although the differences associated with gender are small ( 0.6 percentage points).

Finally, the (perceived) costs and benefits of learning investments might differ between immigrant and native workers. Cohen-Goldner and Eckstein (2010) e.g. show that training participation substantially increases the job-offer rates of female immigrants. However, other studies show that immigrants participate less often in training because of financial constraints (Hum \& Simpson, 2003).

Apart from these individual characteristics, also organisation characteristics may be relevant. The empirical human capital literature shows that those who are employed in a large 
organisation participate more often in training (e.g. Montizaan et al., 2010). This finding suggests that larger organisations have more formally developed and sophisticated HRM policies than small organisations do (Koch \& McGrath, 1996). Participation in informal learning is also highest for those employed in larger organisations (Ferreira et al., 2018). Furthermore, various studies show there are substantial differences in training participation between different sectors of industry that face different benefits of training (Bassanini et al., 2007). The latter also show that training participation is higher in the public sector than in the private sector for all 12 European Union countries they analyse. Grund and Martin (2012) show that, in Germany, training participation is significantly higher in the finance sector, whereas it is significantly lower in the construction sector. We therefore also control for organisation size and sector of industry.

Ferreira et al. (2018) show that informal learning in the workplace is positively related to workers' participation in formal training. This finding illustrates Heckman's (2007) notion of dynamic complementarity: Higher skills increase returns on future investments in learning. This suggests that we might expect the same complementarity to hold for workers' participation in training and their participation in workshops. However, given the high opportunity costs in particular managers and professionals face during the time they spend on training, workplace attendance might also be a cheaper substitute for training. To find out whether and how workshop attendance is related to other modes of learning, we control for both training participation and informal learning.

Although the above-mentioned studies refer to training or informal learning instead of workshop attendance, we might expect that the finding that workers who are less able to reap all the potential benefits from training participate less often will also hold for their workshop attendance. As not including possible confounders might bias our findings on workshop participation, we control for all these individual and organisational characteristics when testing our two hypotheses on the drivers of workshop participation.

\section{Data and methodology}

\section{Data collection and sample}

For our analysis, we use data from the Adult Education Survey (AES) of Statistics Netherlands that was conducted among the 25- to 64-year-olds at the beginning of 2012. Statistics 
Netherlands invited 5,435 persons to participate in the AES. These persons were randomly selected from the Municipal Longitudinal Population Register by applying a two-stage sampling procedure. The first stage resulted in a stratified sample of municipalities. In the second stage, a random sample of persons was drawn from the selected municipalities. All sampled individuals received advance notification in the form of a letter and were contacted by telephone three different times (morning, afternoon, and evening) on three different days. The persons contacted were interviewed by telephone (computer-assisted telephone interviewing). The Adult Education Survey sample is representative for the Netherlands with a few exceptions. Those aged between 55 and 64 years were overrepresented in the sample compared to the same age group in the Dutch population. The same holds for persons in a household with children, and to a lesser extent, persons having a high level of education. The response rate of the survey was $56 \%$, with 3,036 respondents. Of all respondents, $40 \%$ participated in a workshop, $32.5 \%$ in a short course, $12 \%$ in a long course and $32 \%$ learned in an informal way. In the sample, $52.5 \%$ were men and $47.5 \%$ women, $16 \%$ had a low educational level, $42 \%$ an intermediate and $41 \%$ a high level. For more information about other background characteristics of the sample, see Appendix 1. For our multivariate analyses, we use the data of the 2,270 respondents who belong to the working population (i.e. those employed at least 12 hours a week).

\section{Measures}

\section{Participation in workshops, short courses, long courses, and informal learning}

Our definitions of workshops, short and long courses and informal learning build on the definitions in the AES and the underlying Eurostat Classification of Learning Activities (2015). Participation in workshops, short courses, and long courses is assessed by the question whether the respondent participated in at least one of each specific educational activity in the previous year (Eurostat, 2012). ECLA defines workshops as follows: 'Sessions combining theoretical instruction with "hands-on" training provided during a seminar or conference' (p. 21). The AES survey question is formulated as follows: 'Did you go to a workshop or congress, e.g. a workshop in photography or a health congress in the last 12 months? Yes/No'. Since workshops could also be attended for fun, we also include an analysis of workers' participation in workshops that were work related. However, we only have data on the latter if the respondent did not participate in a short course that he or she considered more important than participating in a workshop.

Workshops do not include short courses, which are defined as learning activities organised in a classroom for a group of people and built around the transmission of knowledge by a teacher 
or instructor with the intention of providing instructions and education. This may or may not include discussion on a given subject, such as job-related courses. In the current study, the duration of a short course is defined as less than six months.

Long courses are defined as institutionalized learning activities with a duration of at least six months that lead to a learning achievement that can be positioned in the National Framework of Qualifications, so-called formal education. The National Framework of Qualifications recognizes learning activities constituted of structured hierarchical programmes with a chronological succession of levels and grades, admission requirements, and formal registration.

Participation in informal learning is measured by the following question: 'Other than the activities discussed earlier, have you deliberately tried to learn anything at work or during your free time to improve your knowledge or skills in the last 12 months?' The term deliberately was here added according to the Classification for Learning Activities (Eurostat 2015) in order to exclude random learning.

Our data show that workshop attendance is as important as participation in a training course. In the previous year (i.e. 2011), $40 \%$ of the working population attended a workshop, whereas $41 \%$ participated in a short and/or long training course and $32 \%$ learned in an informal way. Our data also show that $71 \%$ of those who were employed participated in one or more modes of learning. Table 1 shows the means and standard deviations of the variables included in our study for both those who attended a workshop and those who did not. These descriptive statistics are described in the remainder of this section. The table shows that the extent of participation in a short course and informal learning is much greater among those who attended a workshop than among those who did not. Across workshop participants, $40 \%$ also participated in a short course and 39\% participated in informal learning compared to, respectively, $27 \%$ and $28 \%$ of those who did not attend a workshop.

[Table 1]

\section{Potential drivers of workshop attendance}

In our analysis, we include several individual, job and organisation characteristics that are potential drivers of workshop attendance as suggested in the hypotheses formulated above: occupation (hypothesis 1) and level of education (hypothesis 2). Furthermore, we include control variables on the permanency of the job, number of contractual working hours, age, gender, origin, organisation size, and economic activity of the organisation's local 
establishment. Moreover, we test whether workshop attendance is related to worker participation in formal training and informal learning. Table 1 compares the workshop participants and non-participants in terms of the various personal and career characteristics, job characteristics, and organisation characteristics included in our analyses, respectively.

Among the workshop participants, the two occupational groups referred to in Hypothesis 1 managers and professionals) are both highly overrepresented (see Table 1). 38\% of those who attended a workshop are professionals, whereas $14 \%$ have a management job. Among the nonparticipant these percentage of professionals (19\%) and managers (6\%) are much lower. To classify occupations, the standardised International Classification of Occupations of the International Labour Organization (2017) is used, which represent all possible occupations. Occupations are classified into the ten major groups of the International Classification of Occupations. In this classification 'Professionals', for example, are defined as follows: "Professionals increase the existing stock of knowledge, apply scientific or artistic concepts and theories, teach about the foregoing in a systematic manner, or engage in any combination of these activities". Managers are defined as those who "plan, direct, coordinate and evaluate the overall activities of enterprises, governments and other organisations, or of organisational units within them, and formulate and review their policies, laws, rules and regulations." The International Classification of Occupations distinguishes the following sub-major groups of managers: (1) Chief Executives, Senior Officials and Legislators, (2) Administrative and Commercial Managers, (3) Production and Specialized Services Managers and (4) Hospitality, Retail and Other Services Managers.

With respect to the respondents' level of education, we distinguish between the low, intermediate, and high educated. Table 1 shows that $23 \%$ of the non-participants have a low level of education, whereas $47 \%$ and $30 \%$ have intermediate and high levels of education, respectively. Among the workshop participants, the percentage of the low (6\%) and intermediate $(35 \%)$ educated is much lower, whereas almost twice as many of the nonparticipants (58\%) are higher educated.

Workshop participants and non-participants hardly differ in age, whereas women appear to participate more often than men do and non-Western migrants are underrepresented among workshop participants. For economic activity, the standardised classification of Eurostat (2008) is used, which represent all possible economic activities. Economic activities are divided into nine groups, which are based on the sections of the NACE rev.2 classification (Eurostat 2008). 
The economic activity 'Information and communication', for example, is defined as follows: "This section includes the production and distribution of information and cultural products, the provision of the means to transmit or distribute these products, as well as data communications, information technology activities and the processing of data and other information service activities" (Eurostat, 2008, p. 247).

Table 1 shows that workshop attendance is particularly high among those employed in the public sector (public administration, education, and health) and the finance and insurance sector, whereas those employed in the construction sector are underrepresented among workshop participants. Furthermore, the table shows that those employed in a temporary job less often attend workshops, whereas there are only small differences in workshop attendance between part-time and full-time workers. Moreover, workshop attendance is particularly high among those who are employed in a larger organisation.

Table 2 shows the correlations between levels of participation in the various modes of learning. As expected, participation in workshops is significantly positively related to participation in short courses (0.182), long courses (0.061), and informal learning (0.143). However, the positive relation between workshop participation and participation in long courses is very small. Participation in short and long courses does not appear to be correlated, but there is a significant positive relation between informal learning and participation in short training courses $(0.119)$ and long courses (0.075). Although these correlations are all significant, they are small.

\section{[Table 2]}

\section{Methodology}

Since workshop attendance is not linearly scaled, we estimate a logistic regression on the drivers of (job-related) workshop attendance and several control variables. Logistic regression is usually applied when the response variable is binary or dichotomous (Hosmer \& Lemeshow, 2000). In a logistic model, the log-odds of the probability of an event (in this case workshop attendance) is a linear combination of independent variables (in our study several individual, job-related and organisation-related characteristics). This model assumes that the coefficients are only additive on the logit scale, which is nonlinear, in contrast to e.g. a linear regression model. In our logistic regression analysis, odds ratios are calculated which can be used to determine whether a particular exposure (e.g. having a high educational level) is related to 
workshop attendance, and to compare the magnitude of various determinants for workshop attendance. The odds ratio is a measure of association between an exposure and an outcome. It here represents the odds that workshop attendance will occur given a particular exposure (e.g. having a high educational level), compared to the odds of the outcome occurring in the absence of that exposure (e.g. having a low educational level). For all one-dimensional variables (level of education, working hours and organization size), we use the lower category as reference value as is common practice in the literature. For other variables we use a category different from the variable of interest as reference category (e.g. craft and related trade workers, permanent job, native worker).If the odds ratio is larger than 1 the outcome (workshop participation) is more likely; if the odds ratio is lower than 1 the outcome is less likely.

In the logistic regressions conducted in the present study, we include various job- and organisation-related variables. To compare the determinants of workshop attendance with those of other modes of learning, we estimate similar logistic regressions on worker participation in short training courses, long courses, and informal learning.

\section{Results}

\section{Workshop attendance}

Table 3 shows the estimation results of a logit analysis on the drivers of workshop attendance. The estimation results of Column 1 include participation in all workshops, whereas Column 2 only includes job-related workshops. Tjur's $\mathrm{R}^{2}$ values (Tjur's $\mathrm{R}^{2}=.181$ and .112 respectively) indicate that the models make reasonable predictions as these values are not extremely high or low. However, relatively low $\mathrm{R}^{2}$ values are standard in logistic regression (Hosmer \& Lemeshow, 2000). Table 3 shows that the results of both estimations are quite similar. As expected the odds ratios show that workshop attendance is substantially higher for managers and professionals, with odds ratios of 2.5 and 1.9 respectively. These findings confirm hypothesis 1 . Those who have an intermediate level of education participate twice as much in workshops than the low educated, whereas the higher educated participate three times as much in workshops. These results confirm hypothesis 2 .

With respect to our control variables, we find that those with a temporary contract less often attend workshops than those with a permanent contract do (odds ratio 0.7). However, the estimation results further show that workshop attendance is not significantly related to the 
number of contractual working hours. This result contradicts the lower training participation of part-time workers found in other studies.

We find a non-linear pattern for worker age. Workshop attendance appears to be highest during workers' mid-career years. Combining the odds ratios of the age and age-squared variables shows that workshop attendance increases until the age of 47 but rapidly decreases thereafter. As the estimated odds ratio of the age variable is larger than 1 and the estimated coefficient of the age square variable is smaller than 1 , we can easily calculate this peak value. At the age of 30 , the probability of participating in a workshop is $32 \%$, compared to $45 \%$ for those who are 45 years old and $37 \%$ for those aged $60 .^{3}$ Furthermore, Women do not appear to attend workshops less or more often than male workers. Table 3 also shows there is no significant difference in workshop attendance between immigrants and natives. However, it should be noted that the odds ratios for migrants are below one and their non-significance could be due to the low number of migrants in our dataset.

Moreover, workshop attendance does not differ between the employees of small and larger organisations. This result also differs from the findings of studies on formal training that generally show a lower training participation of those employed in smaller organisations (e.g. Kyndt \& Baert, 2013). With respect to the industry sector, the estimation results show that workshop attendance is highest in the finance and the arts, entertainment and recreation sectors, with odds ratios of 2.8 and 2.3, respectively. We also find that workshop attendance is high in the public sector (odds ratio 1.9).

Finally, the estimation results of Column 1 in Table 3 show that workshop attendance is positively related to worker participation in training courses. However, the association with informal learning is not significant. Although the estimation results of Column 2 of Table 3 suggest that participation in job-related workshops is negatively related to participation in short courses, it should be noted that this is an artefact of our dataset, since participation in job-related workshops could only be reported if the respondent considers these to be more important than any other short course in which he or she participated.

[Table 3]

\footnotetext{
${ }^{3}$ Additional estimates on workshop participation for all 25- to 65-year-olds show a large gap in workshop participation between the employed and unemployed, particularly for those over 60 .
} 


\section{Participation in training and informal learning}

Table 4 enables us to compare our findings on the drivers of workshop attendance with those of participation in short training courses, long courses, and informal learning. The applied models have limited predictive power (Tjur's $\mathrm{R}^{2}$ are between .059 and .135). The estimation results show that the higher educated also participate more in long training courses and informal learning. The odds ratios are particularly high for informal learning. However, higher educated workers do not appear to participate significantly more in shorter training courses. For managers, the higher participation in workshops is not reflected in a higher participation in training or informal learning. This result clearly shows that managers are particularly eager to develop their knowledge by participating in workshops. The estimation results find a rather similar pattern for professionals, although the latter are also involved significantly more in informal learning.

\section{[Table 4]}

The estimation results do not show that workers with temporary contacts also participate less in short training courses. However, they appear to participate more often in both long courses and informal learning. The higher participation in long training courses is not in line with the findings of other studies (e.g. Fouarge et al., 2012). However, it could be explained by Autor's (2001) finding, that organisations train temporary workers because this enables them to screen their employees' skills and abilities. The higher participation of temporary workers in informal learning has also been found by Ferreira et al. (2018), although they use a different measure of informal learning. This suggests that temporary jobs could be stepping stones to better jobs. We also do not find that part-time workers participate less often in training courses or long courses. However, we find that full-time workers participate significantly more often in informal learning.

Table 4 shows that older workers participate less often in long courses. The latter confirms findings from other studies that older workers participate less often in training (e.g. Bassanini et al., 2007). However, the lower training participation of older workers does not hold for short courses and informal learning in the workplace. Furthermore, the estimation results show that the modes of learning of women differ from those of male workers. Whereas female workers participate as often as men in workshops and informal learning, they participate less in short training courses. Migrants also do not participate less often in short or longer training courses 
and informal learning. However, the odds ratios we find here are below one and their nonsignificance could be due to the low number of migrants in our dataset.

Those employed in larger organisations appear to participate more often in both short and long training courses. This result confirms those of various other studies (e.g. Kyndt \& Baert, 2013). Since this does not hold for workshop attendance, our findings suggest that workshop attendance could have a lower threshold for those employed in smaller organisations than participation in training does. The same could hold for participation in informal learning, which also does not differ between those employed in smaller and larger organisations. With respect to the sector of industry, the estimation results show that those employed in the finance and insurance sector and those who work in the public administration, education and health sector participate much more often in short training courses and long courses. Finally, our estimation results show that participation in short training courses is not only positively related to workshop attendance but also complementary to informal learning. The latter result is in line with the findings of Ferreira et al. (2018). However, attending short courses appears to be a substitute for worker participation in long courses.

\section{Conclusion and discussion}

Whereas a great many studies in the educational science, HRM and labour economics literature analyse the drivers of participation in training courses, this study is the first that focuses on a currently very popular learning route: attending workshops. We have found that, in the Netherlands, workshop attendance is as high as participation in training courses and higher than participation in informal learning. In $2011,40 \%$ of the Dutch 25 - to 65-year-old working population attended a workshop, whereas $41 \%$ participated in a short or long course and $32 \%$ were involved in informal learning.

We find that workshop attendance is by far the highest among managers and professionals. This result confirms our first hypothesis and is in line with the suggestion of Darr et al. (1995) that workshop attendance can be an important way of learning from other professionals in the same occupational field outside the organisation where one is employed. The high workshop attendance of managers is also in line with the notion in the literature of the absorptive capacity of organisations (e.g. Jansen et al. 2005; Lichtenthaler, 2009), that state-of-the art knowledge on external developments is a dominant source of competitive advantage for the organisation 
since participation in workshops helps both managers and professional staff to acquire new knowledge in their field of expertise and to extend their external networks in these issues.

Moreover, workshop attendance appears to be positively related to workers' level of education, which confirms our second hypothesis. Those who have a temporary contract less often attend workshops. This is consistent with expectations from Human capital theory. However, it shows that workers with temporary contracts have less opportunities for networking at workshops than those with a permanent, which might be a handicap for finding a position in another organisation.

During a worker's life course, workshop attendance appears to be highest in the mid-career years. For those who are employed, workshop attendance peaks at the age of 47 . At the age of 30 , the probability of participating in a workshop is $32 \%$, compared to $45 \%$ for those 45 years old and $37 \%$ for those aged 60 . Particularly for older employed workers, the probability of participating in a workshop is far higher than for the inactive in this age group. Moreover, there are also significant differences between industry sectors: Workshop attendance is highest for those employed in the finance and insurance, entertainment, and non-profit sectors. Finally, workshop participation seems to be complementary to participation in short courses. However, this does not hold for job-related workshops, which appears to be a substitute for participation in short courses.

Our estimation results show that the drivers of workshop attendance are different from the determinants of workers' participation in training courses and informal learning. Managers and professionals more often attend workshops, whereas they do not more often participate in short or long courses than other workers do. Managers also do not more often learn in an informal way at work. These results suggest that, for managers, particularly workshop attendance is important for acquiring new knowledge and skills that is important for the absorptive capacity of the organisation. Those who are higher educated also more often attend workshop as well as more often participate in long courses and informal learning.

And whereas attending workshops appears to be a more important mode of learning later in one's career, training participation and informal learning are highest in the early career. Furthermore, whereas female workers participate less often in short training courses than their male colleagues, they do not differ in workshop attendance. 
Workshop attendance does not appear to differ between those who are employed in small or larger firms. This is an interesting finding as workers employed in larger organisations participate more often in training than those employed in small and medium-sized organisations. This suggests that managers and professionals who are employed in small and medium-sized organisations do not face a higher threshold for workshop attendance than those who are employed in larger organisations.

Furthermore, we have analysed whether workshop attendance is complementary to training participation or a substitute. Our estimation results show that in general workshop attendance is not a substitute for training participation. Instead, those who participate in short training courses also more often attend workshops, which supports Heckman's (2007) notion of dynamic complementarity. However, we did not find evidence for a significant relation between workshop attendance and longer training courses or informal learning.

This study was subject to some limitations. First, as the Adult Education Survey is a legallyembedded survey, we had to adhere to Eurostat's definitions of the different learning modes. We were therefore limited in the way we could operationalise the different learning modes. Second, one could ask whether the results of this study can be generalised to other countries. The Adult Education Survey is an international survey. Output specifications of this survey are harmonised across the EU member states, which enhances international comparability over European countries. Although education systems and labour market institutions are different in other countries, we might expect that findings would be similar in other developed countries, as the organisation of workshops and conferences for higher educated, professionals and managers seems to be booming in many countries. However, further research is needed to draw stronger conclusions about the generalisability of our findings to other countries.

Although the Adult Education Survey is a well-developed Eurostat survey including most of the drivers of training participation distinguished in the literature (see, e.g. Kyndt \& Baert, 2013; Bassanini et al., 2007), it does not include information on personality traits, whereas Fouarge et al. (2013) show that workers' training participation is related to their locus of control and openness to experience, whereas Offenhaus (2013) shows that it is related to conscientiousness. Further research on workshop attendance would therefore particularly benefit from longitudinal 
studies that control for potential time-invariant confounders by means of fixed-effects analyses and therefore rules out the effects of personality traits.

Furthermore, the nature of the survey data we use does not allow us to test whether the expected individual learning processes that could explain the drivers of workshop attendance actually occur. This sets the agenda for further research on the actual knowledge and skills individuals acquire when they attend a workshop or conference and to what determines its transfer to the work place (See De Grip \& Sauermann, 2013).

Our analyses clearly show that it is highly relevant to consider workshop attendance as a different mode of learning, since workshop attendance seems to play a major specific role: attending workshops and conferences enables organisation managers as well as higher educated professionals to be informed on state-of-the art knowledge on external developments in their sector of industry or profession. Since this exploratory learning initiates the organisation's learning process (Lichtenthaler, 2009), it could be a major source of competitive advantage for the organisation by increasing its absorptive capacity. More research on the effects of workshop attendance on worker and organisation performance should therefore be encouraged. As our study was limited by the cross-sectional data we had to use, further research would benefit highly from labour force and household panels that could be used for longitudinal studies on the drivers of workshop attendance as well as on its effects on workers' skills, performance and employability. Furthermore, case studies at the organisation or sector level would help us to identify the reasons for workshop attendance and possible barriers employees face to attend a workshop more explicitly. Moreover, future research on workshop attendance should focus on the transfer of knowledge in the workplace (see e.g. De Rijdt et al., 2013) in order to identify the ways in which the transfers of knowledge across organisations shown in Darr et al. (1995) are affected.

\section{References}

Autor, D. (2001). Why do temporary help firms provide free general skills training? Quarterly Journal of Economics, 116, 1409-1448.

Bassanini, A., Booth, A., Brunello, G., De Paola, M., \& Leuven, E. (2007). Workplace training in Europe. In G. Brunello, P. Garibaldi, \& E. Wasmer (Eds.), Education and training in Europe (pp. 143-309). Oxford: Oxford University Press. 
Becker, G.S. (1962). Investment in Human Capital: A Theoretical Analysis, Journal of Political Economy, 70(5), Part 2, 9-49.

Booth, A. L., Francesconi, M. \& Frank, J. (2002). Temporary jobs: Stepping-stones or dead ends? Economic Journal, 112, F189-F213.

Brockmeyer, M.A. (1998). The impact of an extended inquiry-based in-service program on the beliefs and practices of beginning secondary science teachers. Unpublished doctoral thesis, Iowa City: University of Iowa.

Burke, L. A. \& Hutchins, H. M. (2007). Training transfer: An integrative literature review. Human Resource Development Review, 6, 263-296.

Cohen-Goldner, S. \& Eckstein, Z. (2010). Estimating the return to training and occupational experience: The case of female immigrants, Journal of Econometrics, 156, 86-105.

Cohen, W. M. \& Levinthal, D. A. (1990). Absorptive capacity: a new perspective on learning and innovation. Administrative Science Quarterly, 35, 128-152.

Darr, E.D., Argote, L., \& Epple, D. (1995). The Acquisition, transfer and depreciation of knowledge in service organizations: Productivity in franchises. Management Science, $41,1750-1762$.

De Grip, A. (2015). The importance of informal learning at work. Bonn: IZA World of Labor.

De Grip, A. \& Sauermann, J. (2013). The effect of training on productivity: The transfer of on-the-job training from the perspective of economics. Educational Research Review, $8,28-36$.

De Grip, A., Sauermann, J., \& Sieben, I. (2016). The role of peers in estimating tenureperformance profiles: Evidence from personnel data. Journal of Economic Behavior \& Organization, 126, 39-54.

De Grip, A. \& Smits, W. (2012). What affects lifelong learning of scientists and engineers? International Journal of Manpower, 33, 583-597.

De Grip, A., Van Loo, J., \& Mayhew, K. (Eds.) (2002).The economics of skills obsolescence. Research in Labor Economics, 21. Amsterdam/Boston: JAI Press.

De Rijdt, C., Stes, A., Van der Vleuten, C., \& Dochy, F. (2013). Influencing variables and moderators of transfer of learning to the workplace within the area of staff development in higher education: Research review. Educational Research Review, 8C, $48-74$.

Eurostat (2015). Classification for learning activities. Manual (update). Luxembourg: Eurostat. 
Eurostat (2009). Significant country differences in adult learning. Statistics in focus, 44, 1-12. http://ec.europa.eu/eurostat/documents/3433488/5281333/KS-SF-09-044EN.PDF/82cd034b-a65f-47ca-8f62-6285ad593c20

Eurostat (2008). Statistical classification of economic activities in the European Community (NACE Rev. 2). https://ec.europa.eu/eurostat/documents/3859598/5902521/KS-RA07-015-EN.PDF

Eurostat (2014). Information society statistics: Households and individuals, Eurostat statistics explained. http://ec.europa.eu/eurostat/statisticsexplained/index.php/Information_society statistics - households and individuals . Eurostat (2012). AES Manual version 8. Luxembourg: Eurostat.

Fenwick, T. (2012). Learning among older professional workers: Knowledge strategies and knowledge orientations. Vocations and Learning, 5, 203-223.

Ferreira, M., De Grip, A., \& Van der Velden, R. (2018). Does on-the-job informal learning in OECD countries differ by contract duration? Labour Economics, 55, 18-40.

Fouarge, D., De Grip, A., Smits, W., \& De Vries, R. (2012). Flexible contracts and human capital investments. De Economist, 160, 177-195.

Fouarge, D., Schils, T., \& De Grip, A. (2013). Why Do Low-Educated Workers Invest Less in Further Training? Applied Economics, 45, 2587-2601.

Froehlich, D. E., Beausaert, S. A. J., \& Segers, M. S. R. (2014). Age, employability and the role of learning activities and their motivational antecedents: a conceptual model. International Journal of Human Resource Management, 25, 1-15.

Greenhalgh C. \& Mavrotas G. (1996). Job training, new technology and labour turnover. British Journal of Industrial Relations, 34, 131-150.

Grund, C. \& Martin, J. (2012). Determinants of further training: evidence for Germany. International Journal of Human Resource Management, 23, 3536-3558.

Harteis, C., Billett, S., Goller, M., Rausch, A., \& Seifried, J. (2015). Effects of age, gender and occupation on perceived workplace learning support, International Journal of Training Research, 13, 64-81.

Heckman, J. (2007). The economics, technology and neuroscience of human capability formation. PNAS, 104, 13250-13255.

Hosmer, D.W. \& Lemeshow, S. (2000). Applied logistic regression (2 ${ }^{\text {nd }}$ Ed.). New York: Wiley.

Hum, D. \& Simpson, W. (2003). Job-related training activity by immigrants to Canada. Canadian Public Policy, 29, 469-490 
International Labour Organization (2017). International Standard Classification of Occupations (ISCO) 2008. http://www.ilo.org/public/english/bureau/stat/isco/isco08/ Jansen, J. J. P., Van Den Bosch, F. A. J., \& Volberda, H. W. (2005). Managing potential and realized absorptive capacity: how do organizational antecedents matter? Academy of Management Journal, 48, 999-1015.

Koch, M. \& McGrath, R. (1996). Improving labor productivity: human resource management policies do matter. Strategic Management Journal, 17, 335-354.

Kyndt, E. \& Baert, H. (2013). ‘Antecedents of employees' Involvement in work-related learning: A systematic review. Review of Educational Research, 83, 273-313.

Lichtenthaler, U (2009). 'Absorptive capacity, environmental turbulence, and the complementarity of organizational learning processes. Academy of Management Journal, 52, 822-846.

Llewellyn, R. S., Pannell, D.J., Lindner, R. K., \& Powles, S. B. (2006). Targeting key perceptions when planning and evaluating extension. Australian Journal of Experimental Agriculture, 45, 1627-1633.

RG McGrath (2001) Exploratory learning, innovative capacity, and managerial oversight, Academy of Management Journal, 44, 118-131

Montizaan, R., Cörvers, F., \& De Grip, A. (2010). The effects of pension rights and retirement age on training participation: Evidence from a natural experiment. Labour Economics, 17, 240-247.

Nelen, A. \& De Grip, A. (2009). Why do part-time workers invest less in human capital than full-timers? Labour, 23, 61-83.

Noe, R. A., Tews, M. J., \& Marand, A. D. (2013). Individual differences and informal learning in the workplace. Journal of Vocational Behavior, 83, 327-335.

Offerhaus, J. (2013) The Type to Train? Impacts of Personality Characteristics on Further Training Participation. SOEPpaper 531 http://dx.doi.org/10.2139/ssrn.2205028

Rüber, I. E. \& Bol, T. (2017). Informal learning and labour market returns: Evidence from German Panel Data. European Sociological Review, 33, 765-778.

Stamov-Roßnagel, C. (2009). All is not decline: giving the change multiple directions. Industrial and Organizational Psychology, 2, 112-114.

Tushman, M. L. (1977). Communication across organizational boundaries: Special boundary roles in the innovation process. Administrative Science Quarterly, 22, 587-605.

Van der Heijden, B. I. J. M., Boon, J., Van der Klink, M. R., \& Meijs, E. (2009).

Employability enhancement through formal and informal learning: An empirical study 
among Dutch non-academic university staff members. International Journal of Training and Development, 13, 19-37. 
Mean

SD N

\section{Hypotheses}

Occupation

Craft and related trades workers

Professionals

Technicians and associate professionals

Clerical support workers

Managers

Service and sales workers

Other occupations ${ }^{1}$

Educational level

Low

Intermediate

High

\section{Control variables}

Permanency of the job

Permant job or work contract of unlimited duration

Temporary job or work contract of limited duration

Self-employed worker

Contractual working hours

12 to 19 hours a week

20 to 28 hours a week

29 to 34 hours a week

35 to 94 hours a week

Age (years)

$\operatorname{Age}^{2}\left(\right.$ years $\left.^{2}\right)$

Sex

Male

Female

Origin

Native

Western immigrant

Non-Western immigrant
928

, $09 \quad 29$

,38 ,49

$, 20 \quad, 40$

, $07 \quad 25$

,14 ,34

$, 04 \quad, 19$

, $09 \quad 28$

928

$0,06 \quad 0,24$

$0,35 \quad 0,48$

$0,58 \quad 0,49$

,79 ,41

,07 26

,14 ,35

928

,08 , 28

,20 ,40

,15 ,36

$, 57 \quad, 50$

$46,07 \quad 9,31$

$2.208,73 \quad 840,73$

928

,51 ,50

$, 49 \quad, 50$

928

, $91 \quad 29$

,07 26

,02 ,15
923

\begin{tabular}{lll} 
Mean & SD & $\mathrm{N}$ \\
\hline
\end{tabular}

,13 ,34

,19 ,39

,18 ,39

,12 ,32

,06 24

,12 ,32

$, 19 \quad, 40$

1.373

$\begin{array}{rr}0,23 & 0,42 \\ 0,47 & 0,50 \\ 0,3 & 0,46\end{array}$

$0,3 \quad 0,46$ 
Wholesale and retail trade, transportation, accomodation

Manufacturing and energy supply

\section{Construction}

Information and communication

Financial and insurance activities

Professional, scientific and technical activities,

administrative and support survice activities

Public administration and defence, compulsory social security,

, $06 \quad 25$

,02 , 15

,03 , 17

,06 24

$, 10 \quad, 30$

\section{, 46}

\section{, 50}

,04 20

,14 ,35

Other economic activties ${ }^{3}$

\section{Modes of learning}

Participation in course

Participation in long course

Participation in informal learning

,14 ,34

$, 39 \quad, 49$

${ }^{1}$ The occupational categories "skilled agricultural, forestry and fishery workers", "plant and machine operators and assemblers", "operators", "elementary occupations", "armed forces occupations", and "unkown" are small and are therefore merged into a category "other occupations".

${ }^{3}$ The economic activity groups "agriculture, forestry and fishing ", "real estate activties", and "unknown" are small and are therefore merged into a category "other economic activities". 
Table 2. Correlation coefficients between four modes of learning: workshops, short courses, long courses and informal learning

\begin{tabular}{lcccc}
\hline & Workshops & Short courses & Long courses & Informal learning \\
\hline Workshops & - & & & \\
Short courses & $.182^{* *}$ & - & & \\
Long courses & $.061^{* *}$ & .014 & - & - \\
Informal learning & $.143^{* *}$ & $.119^{* *}$ & $.075^{* *}$ & - \\
\hline
\end{tabular}

Phi coefficient, $* * \mathrm{p}<0.01, * \mathrm{p}<0.05$ (two-tailed) 
Table 3. Workshop participation among working population (25 to 65 years): estimation results (t statistics in parentheses)

Job-

Workshops related

workshops

\section{Hypotheses}

Occupation (reference Craft and related trades workers)

Professionals

Technicians and associate professionals

$(.30)$

Clerical support workers

$.889 \quad .959$

Managers

$(-.12) \quad(-.04)$

$2.512 * * \quad 2.490 * *$

Service and sales workers

(.92) (.91)

$1.281 \quad 1.128$

(.25) $\quad(.12)$

Other occupations ${ }^{1}$

$.894 \quad .848$

$(-.11) \quad(-.17)$

Educational attainment level (reference Low)

Intermediate

$2.045 * * \quad 1.779 * *$

High

\section{Control variables}

Permanency of the job (reference Permanent job or work contract of unlimited duration)

Temporary job or work contract of limited duration

$\begin{array}{cc}.693 * & .700 \\ (-.37) & (-.36) \\ .841 & .962 \\ (-.17) & (-.04)\end{array}$

Contractual working hours (reference 12 to 20

contractual working hours a week)

20 to 28 hours a week

$\begin{array}{ll}.818 & .763 \\ (-.20) & (-.27) \\ 1.083 & 1.043 \\ (.08) & (.04) \\ 1.281 & 1.196 \\ (.25) & (.18)\end{array}$

Age (years) 


$\begin{array}{lcc} & (.09) & (.06) \\ \text { Age }^{2}\left(\text { years }^{2} / 100\right) & .740^{* *} & .888^{*} \\ & (-.21) & (-.12) \\ & & \\ \text { Female } & 1.119 & 1.187 \\ & (.18) & (.17) \\ \text { Origin (reference Native) } & & \\ \text { Western immigrant } & .844 & .729 \\ & (-.17) & (-.32) \\ \text { Non-Western immigrant } & .756 & .643 \\ & (-.28) & (-.44) \\ & & \\ \text { Organisation size (local unit, reference } & & \\ \text { firms }<10 \text { employees) } & & \\ 10 \text { to } 99 \text { employees } & .735 & .758 \\ & (-.31) & (-.28) \\ 100 \text { or more employees } & 1,279 & 1,066 \\ & (.25) & (.06)\end{array}$

\begin{tabular}{|c|c|c|}
\hline \multicolumn{3}{|l|}{ Economic activity of the local unit } \\
\hline (reference wholesale and retail trade) & & \\
\hline \multirow[t]{2}{*}{ Manufacturing, energy supply } & .928 & 1.056 \\
\hline & $(-.07)$ & $(.05)$ \\
\hline \multirow[t]{2}{*}{ Construction } & .577 & .748 \\
\hline & $(-.55)$ & $(-.29)$ \\
\hline \multirow[t]{2}{*}{ Information and communication } & .833 & .968 \\
\hline & $(-.18)$ & $(-.03)$ \\
\hline \multirow[t]{2}{*}{ Finance and insurance } & $2.767 * *$ & $2.396 * *$ \\
\hline & $(1.02)$ & $(.87)$ \\
\hline \multirow[t]{2}{*}{ Professional, technical and administrative activities } & 1.515 & 1.530 \\
\hline & $(.42)$ & $(.43)$ \\
\hline \multirow[t]{2}{*}{ Public administration, education and health } & $1.858 * *$ & $2.001 * *$ \\
\hline & $(.62)$ & (.69) \\
\hline \multirow[t]{2}{*}{ Arts, entertainment and recreation } & $2.328^{* *}$ & $1.891 *$ \\
\hline & $(.85)$ & $(.64)$ \\
\hline \multirow[t]{2}{*}{ Other economic activties ${ }^{3}$} & $1.641 *$ & $1,571^{*}$ \\
\hline & $(.50)$ & $(.45)$ \\
\hline \multirow[t]{2}{*}{ Participation in short courses (reference No) } & $1.488^{* *}$ & $.258^{* *}$ \\
\hline & $(.40)$ & $(-1.35)$ \\
\hline \multirow[t]{2}{*}{ Participation in long courses (reference No) } & .984 & 1.206 \\
\hline & $(-.02)$ & $(.19)$ \\
\hline \multirow[t]{2}{*}{ Participation in informal learning (reference No) } & 1.180 & .904 \\
\hline & $(.17)$ & $(-.10)$ \\
\hline & $.040^{* *}$ & $.052^{* *}$ \\
\hline
\end{tabular}


Notes: $* \mathrm{p}<0.05, * * \mathrm{p}<0.01$

Logit models for participation in workshops and job-related workshops.

${ }^{1}$ The occupational categories "skilled agricultural, forestry and fishery workers", "plant and machine

operators and assemblers", "operators", "elementary occupations", "armed forces occupations", and "unkown" are small and are therefore merged into a category "other occupations".

${ }^{3}$ The economic activity groups "agriculture, forestry and fishing ", "real estate activties", and "unknown" are small and are therefore merged into a category "other economic activities". 
Table 4. Participation in courses and informal learning among working population (25 to 64 years): estimation results ( $t$ statistics in parentheses)

$\begin{array}{ccc}\text { Short } & \text { Long } & \text { Informal } \\ \text { courses } & \text { courses } & \text { learning }\end{array}$

\section{Hypotheses}

Occupation (reference Service and sales workers)

Professionals

$\begin{array}{ccc}1.221 & 1.169 & 1.759 * \\ (.20) & (.16) & (.57) \\ 1.164 & 1.184 & 1.494 \\ (.15) & (.17) & (.40) \\ .966 & .611 & .988 \\ (-.04) & (-.49) & (-.01) \\ .801 & 1.353 & 1.257 \\ (-.22) & (.30) & (.23) \\ 1.271 & 1.309 & 1.272 \\ (.24) & (.27) & (.24) \\ 1.408 & 1.160 & 1.254 \\ (.34) & (.15) & (.23)\end{array}$

Technicians and associate professionals

Clerical support workers

Managers

Craft and related trades workers

Other occupations ${ }^{1}$

Educational level (reference Low)

Intermediate

$\begin{array}{ccc}1.217 & 1.604 & 2.077 * * \\ (.20) & (.47) & (.73) \\ 1.270 & 2.027 * & 2.786^{* *} \\ (.24) & (.71) & (1.03)\end{array}$

High

\section{Control variables}

Permanency of the job (reference Permanent job or work contract of unlimited duration)

Temporary job or work contract of limited duration

$\begin{array}{ccc}.884 & 2.280 * * & 1.386 * \\ (-.12) & (.82) & (.33) \\ 1.233 & 1.001 & 1.022 \\ (.21) & (.00) & (.02)\end{array}$

Contractual working hours (reference 12 to 20 contractual working hours a week)

20 to 28 hours a week

$\begin{array}{ccc}1.254 & 1.509 & 1.407 \\ (.23) & (.41) & (.34) \\ 1.399 & 1.475 & 1.444 \\ (.34) & (.39) & (.37) \\ 1.278 & 1.398 & 1.637^{*} \\ (.25) & (.34) & (.49) \\ & & \\ .999 & .950^{*} & .996\end{array}$

Age (years) 


$\begin{array}{lcccc} & \text { Age }^{2}\left(\text { years }^{2} / 100\right) & (-.00) & (-.05) & (-.01) \\ & .951 & 1.035 & .996 \\ & (-.05) & (.03) & (-.00) \\ \text { Female } & & & \\ & & & & \\ & & .702 * * & 1.041 & 1.225 \\ & (-.35) & (.04) & (.20)\end{array}$

Origin (reference Native)

Western immigrant

$\begin{array}{lll}.826 & 1.034 \quad 1.142\end{array}$

$(-.19) \quad(.03) \quad(.13)$

Non-Western immigrant

$\begin{array}{lll}.834 & 1.172 \quad .640\end{array}$

$(-.18) \quad(.16) \quad(-.45)$

Organisation size (local unit, reference firms $<10$ employees)

10 to 99 employees

$\begin{array}{ccc}1.171 & 1.552 & .943 \\ (.16) & (.44) & (-.06) \\ 1.603 * & 2.093 * & 1.033 \\ (.47) & (.74) & (.03)\end{array}$

Economic activity of the local unit (reference wholesale and retail trade) $)^{3}$

Manufacturing, energy supply

\begin{tabular}{|c|c|c|}
\hline 1.333 & 1.780 & .958 \\
\hline$(.29)$ & $(.58)$ & $(-.04)$ \\
\hline 1.553 & 1.277 & .705 \\
\hline (.44) & $(.24)$ & $(-.35)$ \\
\hline .872 & 1.184 & 1.377 \\
\hline$(-.14)$ & (.17) & $(.32)$ \\
\hline $2.434 * *$ & $2.870 *$ & .587 \\
\hline$(.89)$ & (1.05) & $(-.53)$ \\
\hline 1.384 & 1.879 & .987 \\
\hline (.33) & (.63) & $(-.01)$ \\
\hline $1.826^{* *}$ & $3.679 * *$ & 1.001 \\
\hline$(.60)$ & (1.30) & $(.00)$ \\
\hline .942 & 1.972 & .877 \\
\hline$(-.06)$ & (.68) & $(-.13)$ \\
\hline .911 & $2.211 *$ & .987 \\
\hline$(-.09)$ & $(.79)$ & $(-.01)$ \\
\hline $1.486^{* *}$ & 1.028 & 1.175 \\
\hline$(.40)$ & $(.03)$ & $(.16)$ \\
\hline & $.695^{*}$ & $1.303 * *$ \\
\hline & $(-.36)$ & $(.27)$ \\
\hline $.697^{*}$ & & 1.115 \\
\hline$(-.36)$ & & $(.11)$ \\
\hline $1.305^{* *}$ & 1.152 & \\
\hline$(.27)$ & (.14) & \\
\hline
\end{tabular}


Notes: $* \mathrm{p}<0.05, * * \mathrm{p}<0.01$

Logit model for participation in short courses, long courses and informal learning.

${ }^{1}$ The occupational categories "skilled agricultural, forestry and fishery workers", "plant and machine operators and assemblers", "operators", "elementary occupations", "armed forces occupations", and "unkown" are small and are therefore merged into a category "other occupations".

${ }^{3}$ The economic activity groups "agriculture, forestry and fishing ", "real estate activties", and "unknown" are small and are therefore merged into a category "other economic activities". 
Total sample

\section{Hypotheses}

\section{Occupation}

Craft and related trades workers

Professionals

Technicians and associate professionals

Clerical support workers

Managers

Service and sales workers

Other occupations ${ }^{1}$

Educational level

Low

Intermediate

High

\section{Control variables}

Permanency of the job

Permant job or work contract of unlimited duration

Temporary job or work contract of limited duration

Contractual working hours

12 to 19 hours a week

20 to 28 hours a week

29 to 34 hours a week

35 to 95 hours a week

Age groups

25 to 34 years

35 to 44 years

45 to 54 years

55 to 64 years

Sex

Male

Female

Origin

Native 
Organisation size (local unit)

$<10$ employees

10 to 99 employees

100 or more employees

\section{Economic activity of the local unit}

Wholesale and retail trade, transportation, accomodation and food service activities

Manufacturing and energy supply

Construction

Information and communication

Financial and insurance activities

Professional, scientific and technical activities, administrative and support survice activities

Public administration and defence, compulsory social security, education, human health and social work activties

Arts, entertainment and recreation, other services

Other economic activties ${ }^{2}$

\section{Modes of learning}

Participation in workshop

\footnotetext{
${ }^{1}$ The occupational categories "skilled agricultural, forestry and fishery workers", "plant and machine operators, and assemblers", "operators", "elementary occupations", "armed forces occupations", and "unkown" are small and are therefore merged into a category "other occupations".

${ }^{2}$ The economic activity groups "agriculture, forestry and fishing ", "real estate activties", and "unknown" are small and are therefore merged into a category "other economic activities".

*For the variables educational level, occupation and organisation size the totals do not add up to the sample total as for some persons it is unknown to which category they belong.
} 